\title{
Increased antral follicle population and in vitro embryo production in pregnant Holstein
}

\section{Aumento da população folicular antral e produção in vitro de embriões em fêmeas gestantes da raça Holandesa}

\author{
Ricardo Guella Droher ${ }^{1}$; Fabio Luiz Bim Cavalieri²; Fabio Morotti3; \\ Amanda Fonseca Zangirolamo3; Marcia Aparecida Andreazzi4; \\ Marcelo Marcondes Seneda ${ }^{5 *}$
}

\section{Highlights}

Antral follicle count (AFC) is an important reproductive characteristic in cattle.

Pregnancy positively influences AFC in Holstein cattle.

In vitro embryo production improved when oocytes were collected from pregnant donors.

\begin{abstract}
This study used Holstein cattle to evaluate the following: I) the productive and reproductive characteristics of cows with low, intermediate and high antral follicle counts (AFCs) that were subjected to artificial insemination (Al) and comparison of AFC variability at the time of $\mathrm{Al}$ (nonpregnant) and at two time points during pregnancy ( 30 and 60 days), and II) whether the pregnancy status and different pregnancy periods in heifers improves the efficiency at in vitro embryo production (IVEP). In study I, 75 high-milk production cows with body condition scores (BCSs) of 2.75 to 4.75 and ages of 23 to 99 months were selected. On the day of estrus, AFCs (follicles $\geq 3 \mathrm{~mm}$ ), BCS, body weight, and diameters of the dominant follicle, ovaries and the corpus luteum were evaluated. Posteriorly, AFC was monitored in pregnant cows at 30 days $(n=$ 35) and at 60 days for comparison of AFC before pregnancy versus different periods. In study II, heifers ( $n=9$ ) with BCS of 2.5 to 3.5 and ages of 10 to 16 months were selected for ovum pick-up and an IVEP program before $\mathrm{Al}$ (nonpregnant) as well as at 0 to 30, 31 to 60 , and $>60$ days of pregnancy. Statistical analysis was performed using PROC GLM and binary logistic regression model $(P \leq 0.05)$. In study I, AFC was not associated with variations in productive and reproductive parameters. However, AFCs in the low group increased following pregnancy (Al: $14.82 \pm 1.36,30$ days: $23.45 \pm 2.31$ and 60 days: $35.18 \pm 3.17$
\end{abstract}

1 MSc. Animal Science Program, Universidade Estadual de Londrina, UEL, Londrina, PR, Brazil. E-mail: drohervet@ hotmail.com

2 Prof. Dr., Clean Technologies Program, Unicesumar, Maringá, PR, Brazil. E-mail: fbim52@hotmail.com

3 Profs. Drs., Animal Science Program, UEL, Londrina, PR, Brazil. E-mail: fabiomorotti@uel.br; amandafz@uel.br

${ }^{4}$ Profa Dra, Clean Technologies Program, Unicesumar, Maringá, PR, Brazil. E-mail: marcia.andreazzi@unicesumar.edu.br

5 Prof. Dr., Animal Science Program, UEL, Londrina, PR, Brazil. E-mail: marcelo.seneda@uel.br

* Author for correspondence

Received: Mar. 04, 2021 - Approved: June 02, 2021 
follicles). AFCs increased from $\mathrm{Al}$ to 60 days in the intermediate group but did not vary among time points in the high group. AFCs varied among AFC groups in Al and at 30 days of pregnancy but not at 60 days. In study II, the mean of total oocytes $(17.43 \pm 4.52$ vs. $41.67 \pm 3.79)$ and viable oocytes $(13.77 \pm 3.63$ vs. 30.56 \pm 3.45 ) increased from $\mathrm{Al}$ (nonpregnant) to the first 30 days of pregnancy. The mean number of embryos produced increased during pregnancy and during the first 30 days of pregnancy $(4.55 \pm 0.75)$ compared to the nonpregnant period (1.39 \pm 0.85 ). In conclusion, pregnancy positively influences AFC, and the greatest effect is noted in low count cows. In addition, the OPU at the time of pregnancy increased the efficiency of IVEP in heifers.

Key words: Antral follicle count. Dairy cattle. In vitro embryo production. Pregnancy.

\section{Resumo}

Este estudo utilizou fêmeas da raça Holandesa para avaliar: i) variação da contagem de folículos antrais na gestação; ii) resultado da produção in vitro de embriões em doadoras antes e depois da gestação. No estudo I, 75 vacas de alta produção de leite com escores de condição corporal (ECC) de 2,75 a 4,75 e idades de 23 a 99 meses foram selecionadas. No dia do estro a CFA foi avaliada (folículos $\geq 3 \mathrm{~mm}$ ) além do escore corporal, peso corporal e diâmetros do folículo dominante, ovários e corpo lúteo. Posteriormente, a CFA foi monitorada nas vacas gestantes $(n=35)$ aos 30 e 60 dias. No estudo II, novilhas $(n=9)$ com ECC de 2,5 a 3,5 e idades de 10 a 16 meses foram selecionadas para obtenção de oócitos antes e depois da gestação, no primeiro, segundo e acima dos dois meses de gestação. A análise estatística foi realizada usando PROC GLM e modelo de regressão logística binária $(P \leq 0,05)$. No estudo I, a CFA não foi associada a variações nos parâmetros produtivos e reprodutivos. No entanto, as vacas de baixa CFA apresentaram aumento no número de folículos após início da gestação (IA: 14,82 \pm 1,36, 30 dias: 23,45 2,31 e 60 dias: $35,18 \pm 3,17$ folículos). A CFA aumentou da IA para 60 dias no grupo de CFA intermediária, mas não variou ao longo do tempo no grupo de alta CFA. A CFA variou entre os grupos comparando-se o momento da IA e 30 dias de gestação. No estudo II, entre a IA e o primeiro mês de gestação, houve aumento do total de oócitos $(17,43 \pm 4,52$ vs. $41,67 \pm 3,79)$, bem como de oócitos viáveis $(13,77 \pm 3,63$ vs. 30,56 $\pm 3,45)$. 0 número médio de embriões produzidos aumentou durante a gestação, considerando-se o primeiro mês da prenhez $(4,55 \pm 0,75)$ em relação ao período não gestante $(1,39 \pm 0,85)$. Em conclusão, a gestação influencia positivamente a CFA, e o maior efeito foi observado em vacas de baixa CFA. Além disso, a obtenção de oócitos em doadoras gestantes aumentou a eficiência do IVEP em novilhas.

Palavras-chave: Contagem de folículos antrais. Gado leiteiro. Prenhez. Produção de embriões in vitro.

\section{Introduction}

The incorporation of technology and innovation is important for making dairy and beef production systems more efficient, sustainable, and competitive. In this context, reproductive biotechnologies useful, and the antral follicle count (AFC) is associated a variety of fertility-related traits in monovulatory species, such as humans (Zhang et al., 2019), equines (Claes et al., 2017; Gonçalves et al., 2020) and bovines (J. L. H. Ireland et al., 2008; Moraes, Morotti, Costa, Lunardelli, \& Seneda, 2019).

Studies conducted in Europe and the USA suggest a positive association related 
to females (Bos taurus taurus) with high AFCs ( $\geq 25$ follicles) compared to females with low AFCs ( $\leq 15$ follicles; Jimenez-Krassel et al., 2009; J. J. Ireland et al., 2011). Among the effects, an increased pregnancy rate at artificial insemination - Al (Cushman et al. 2009; Mossa et al., 2012) and increased antiMüllerian hormone concentrations $\left(\mathrm{AMH}_{\text {; }}\right.$ Jimenez-Krassel et al., 2015) were found in Holstein cows with high AFCs. Moreover, high AFCs yield a higher number of embryos produced in vitro (J. Ireland et al., 2007) and in vivo by superovulation - SOV (J. L. H. Ireland et al., 2008).

In a study of dairy cattle in New Zealand a higher conception rate was observed in cows with a high AFC ( $\geq 30$ follicles) during the reproductive period (Martinez, Sanderson, Quirke, Lawrence, \& Juengel, 2016). Additionally, in Holstein cows in Japan, higher numbers of oocytes and increased fertility of the aspirated oocytes were observed in a group of cows with high AFCs ( $\geq 25$ follicles) compared to levels observed in a group with low AFCs ( $<25$ follicles) after an in vitro embryo production (IVEP) program (Nagai, Yanagawa, Katagiri, \& Nagano, 2016). Similarly, cows with low AFCs ( $\leq 15$ follicles) were also associated with several low fertility characteristics, such as small ovaries (J. J. Ireland et al., 2011), low endometrial thickness and reduced circulating progesterone concentration (Evans et al., 2012; Jimenez-Krassel et al., 2009).

However, controversial data have recently been reported on zebu animals (Bos taurus indicus) in Brazil regarding $\mathrm{AFC}$ and the reproductive performance of animals subjected to timed artificial insemination (TAI). There are reports of no difference in pregnancy rates between groups with high and low AFCs (Santos et al., 2016), and there are even results with favorable conception rate for the group with a low AFC ( $\leq 15$ follicles; Morotti et al., 2018). Moraes et al. (2019) also observed an 8 - 10\% increased pregnancy rates for cows with low AFCs ( $<10$ follicles) compared with those with intermediate or high AFCs (> 30 follicles) in Bos indicus undergoing TAI.

Other researchers found no difference in the blastocyst yield between donors with low and high AFCs (Bos indicus) submitted to ovum pick-up (OPU) for 12 consecutive months (Monteiro et al., 2017). No difference was observed in ovaries from the slaughterhouse (Rosa et al., 2018). Recently, in contrast to previously presented European and North American studies, shorter productive life and fertility have been reported for taurine (Holstein) females with high AFCs $(\geq 25$ follicles) compared with those animals with intermediate (16 to 24 follicles) and low ( $\leq 15$ follicles) AFCs (Jimenez-Krassel et al., 2017).

The relationship between AFC and the conception rate of high milk-producing taurine dairy cows submitted to Al under management conditions in Brazil has not been investigated to date. Moreover, it is already well established that AFC is variable among animals but highly repeatable in the same female (Burns et al., 2005); however, it is still unknown whether this repeatability is maintained during follicular waves in the early stages of pregnancy.

Additionally, few studies have investigated whether pregnancy interferes with the efficiency of ovum pick-up (OPU) as well as the quantity and quality of recovered oocytes. Takuma et al. (2010) observed that although the morphological quality of the aspirated oocytes was similar between pregnant and nonpregnant females, the developmental competence of the oocytes 
obtained from pregnant cows was greater than the recovered from nonpregnant cows. In mares, a higher quantity of oocytes was also recovered from pregnant compared to cyclical or transitional mares, especially on the 25th day of pregnancy (Purcell, Seidel, McCue, \& Squires, 2007). On the other hand, the relationship between pregnancy status and IVEP efficiency has not been investigated in dairy heifers.

In this study, we hypothesized that AFC may vary with the establishment of pregnancy, which may increase the efficiency of IVEP in dairy cattle. Therefore, the following points were evaluated in Holstein: I) the relationship of AFC with productive and reproductive parameters in cows with high milk production submitted to Al, the AFC variability in cows at the time of $\mathrm{Al}$ (nonpregnant) and at two periods of pregnancy (30 and 60 days), and II) whether the pregnancy status and different pregnancy periods affect the efficiency of OPU and an IVEP program in heifers.

\section{Material and Methods}

This study was conducted according to the Ethics Committee on Animal Experimentation of the State University of Londrina based on Federal Law 11,794 of October 8, 2008 and approved under number 7218.2017.08.

\section{Location}

Study I was conducted during the winter and spring period (July to November 2017), and study II was conducted during the winter and summer period (July to December
2019). Both experiments were conducted in Southern Brazil. Study I was performed on a commercial dairy farm located $24^{\circ} 46^{\prime} 28^{\prime \prime}$ $S$ and $49^{\circ} 56^{\prime} 42^{\prime \prime} \mathrm{W}$ with an elevation of 998 meters. This region has a temperate climate with an average annual temperature of $16.9^{\circ} \mathrm{C}$ and an average annual rainfall of $1553 \mathrm{~mm}$; it is classified as Cfb (Köppen). Study II was conducted on a dairy farm located $23^{\circ} 37^{\prime} 08.7^{\prime \prime}$ $S 52^{\circ} 05^{\prime} 04.2^{\prime \prime} \mathrm{W}$, which has an average annual temperature of $17.5^{\circ} \mathrm{C}$ and rainfall of $1650 \mathrm{~mm}$. In both studies (I and II), Holstein cattle (Bos taurus taurus) were kept in a free stall system and received a balanced feed (composed of corn silage, oat predried, commercial feed, ground corn, cottonseed and mineral core) three times a day according to the required nutritional requirements for each category (National Research Council [NRC], 2001) and water ad libitum.

Study I - Relationship between AFC and productive and reproductive parameters in high milk-producing holstein cows subjected to $A l$

A total of 75 lactating Holstein cows (Bos taurus taurus) that were high milk producers (25 to 50 liters/animal), greater than 30 days postpartum, aged from 23 to 99 months and had a body condition score (BCS) between 2.75 to 4.75 (scale $1-5 ; 1=$ extremely thin and 5 = obese; Ferguson, Galligan, \& Thomsen, 1994) were selected. All animals were confined in a free stall system and received the same nutritional management as described above. Ultrasonographic assessments were performed using transvaginal ultrasound (Aquila Pro Pie Medical, Maastricht, Netherlands) equipped with a 7.5-MHz micro 
convex transducer. The number of antral follicles (AFC); the diameters of the dominant follicle, the ovaries and corpus luteum (CL); the $\mathrm{BCS}$; and the body weight (BW) were assessed during the day of estrus (cows accepting mounts). To determine the AFC, the ovaries (right and left) of each cow were scanned from side to side starting from the ovarian pedicle, and the antral follicle population (all follicles $\geq$ $3 \mathrm{~mm}$ ) was counted as previously described (Burns et al., 2005; Morotti et al., 2018). On the same day, images of the dominant follicle and ovaries were identified and captured, and then diameters were measured using ultrasound images. Ovulation, which was determined by the absence of the dominant follicle and confirmed by the presence of the CL in the same ovary 7 days later, was monitored every $12 \mathrm{~h}$. The CL diameter in the same ovary was assessed, and the largest diameter was measured. The values of each structure were obtained from the average of two perpendicular measurements of each structure. The pregnancy diagnosis was performed 30 days after Al by ultrasound, and pregnant cows ( $\mathrm{n}=$ 35) were reassessed at 60 days of gestation. Therefore, the number of antral follicles (AFC; $\geq 3 \mathrm{~mm}$ in diameter) was evaluated in pregnant cows at each of the following time points: at the time of $\mathrm{Al}$ (day 0; nonpregnant) and two time points of pregnancy (30 and 60 days). Each female was re-evaluated by the same technician and without prior knowledge of the AFC in the previous exam (blind assessment). Based on the AFCs at the time of $\mathrm{Al}$, cows were classified as having a low ( $\leq 18$ follicles; $n=11$ ), intermediate ( $\geq 24$ and $\leq 28$ follicles; $n=11$ ), or high ( $\geq 30$ follicles; $n=13$ ) count, and the AFCs was compared before pregnancy with that at 30 and 60 days of pregnancy.
Study II - Relationship of pregnancy status and different pregnancy periods in the efficiency of IVEP in holstein heifers

To assess whether the variation of AFC before pregnancy (nonpregnant) and at different times of pregnancy affects the IVEP efficiency, Holstein heifers (Bos taurus taurus; $\mathrm{n}=9$ ) from 10 to 16 months and BCS between 2.5 to 3.5 were selected. Al and pregnancy diagnosis were performed as described in Study I. Briefly, the same Veterinary performed $\mathrm{Al}$ of females after the detection of natural or induced estrus with $25 \mathrm{mg}$ of Dinoprost (Lutalyse $^{\circledR}$, Zoetis, Brazil) intramuscularly (IM). Al was performed with commercial semen obtained from the same bull. The diagnosis of gestation was performed at 30 and 60 days after Al. The OPU procedures were performed at different time points: before $\mathrm{Al}$ (15 to 30 days prior $\mathrm{Al}$, nonpregnant) and during pregnancy ( 0 to 30 days, 31 to 60 days, and > 60 days). Immediately after the OPU session, oocytes were evaluated visually using a stereomicroscopic loupe (Nikon SMZ800N, Japan) and classified according to the morphological aspect of the cumulus-oocyte complexes (COCs) following the classification performed by (Lonergan, Rizos, Ward, \& Boland, 2001). After oocyte classification, groups of a maximum of 10 oocytes were placed in drops of maturation medium containing TCM-199 medium (M-3769, Sigma Co., St. Louis, USA). The incubation was performed in an incubator (Panasonic - MCO-19AIC-UV, Japan) with 5\% $\mathrm{CO}_{2}$ at $39^{\circ} \mathrm{C}$ with air and saturated humidity for 24 hours of in vitro maturation (IVM).

For in vitro fertilization (IVF), the semen from a single bull was thawed in a water bath at $35^{\circ} \mathrm{C}$ for 30 seconds. Sperm selection was performedusing the Percoll gradient technique 
(Parrish, Krogenaes, \& Susko-Parrish, 1995). After centrifugation of the semen, its motility was assessed visually. Spermatic capacitation and motility were stimulated with the same fecundation medium, and the concentration of the sperm was adjusted to $1 \times 10^{6}$ spermatozoa/ $\mathrm{mL}$. The oocytes were coincubated with sperm in drops of TALP-FERT fertilization medium (20 mg/mL heparin and PHE; $2 \mathrm{mM}$ penicillin; $1 \mathrm{mM}$ hypotaurine and $250 \mathrm{mM}$ epinephrine). Subsequently, the plates were placed in an incubator with $5 \% \mathrm{CO}_{2}$ at a temperature of $39^{\circ} \mathrm{C}$ with air and saturated humidity for 20 hours. The fertilization day was considered the zero day (D0) of the process.

The blastocyst rate was calculated based on the total viable oocytes aspirated. The embryos were evaluated until Day 7 (Day 0 = day of IVF) according to IETS criteria (Wright, 1998). Blastocyst rate was assessed on Day 7 of culture. Embryos graded as I, II or III were classified as viable.

\section{Statistical analysis}

In study I, the experimental groups were defined as low (Q1 $\leq 18$ follicles; $n=25$ cows), intermediate (cows with $A F C \geq 24$ and $\leq 28$ follicles; $n=25$ cows) and high count ( $Q 3 \geq 30$ follicles; $n=25$ cows). The effect of the number of antral follicles on the studied variables was analyzed using the generalized linear mixed model (GLIMMIX). The main effect of AFC was considered a fixed effect, and all other sources of variation (age, BW, $\mathrm{BCS}$, calving order, days in milk and natural or induced estrus) were included as covariates of the model. Similarly, to evaluate the effect of pregnancy status and 30 and 60 days of gestation on the number of antral follicles, the AFC data were analyzed by repeated measures using the generalized linear model (GLM). The time effect was included as the main effect, and the other sources of variation are included as covariates. Differences in the conception rate of the groups (low, intermediate, and high) were analyzed by binary logistic regression. In study II, the variables of OPU and embryo production were also analyzed by GLIMMIX. The pregnancy status was included as a fixed effect, and the different moments of OPU and donors were included as a random effect. In both studies, the presence of a significant effect and the means were compared using the Tukey test. For descriptive analysis, quantitative data are presented as the mean (M) and standard error (SE), and qualitative data are presented as percentages (\%). All statistical analyses were performed using Minitab $^{\circledR}$ 18.1.1 statistical software, and $P<$ 0.10 was adopted for significance.

\section{Results and Discussion}

The conception rate at 30 and 60 days after conventional $\mathrm{Al}$ was not influenced by the AFC classification $(P>0.1$; Figure 1$)$ in Holstein cows. In general, no differences in the productive and reproductive parameters evaluated in this study were found between cows with low and high AFC $(P>0.1$; Table 1). However, a difference in dominant follicle diameter at $\mathrm{Al}(\mathrm{mm})$ was noted between for animals with intermediate $(18.0 \pm 0.7)$ and high (15.8 $\pm 0.5 ; P=0.04)$ AFCs. Additionally, the weight of the animals with high AFCs (642.4 \pm 12.6) was increased compared with females with low AFCs $(583.5 \pm 17.7 ; P=0.02$, Table 1$)$, and high AFCs exhibited increased BCS (3.6 $\pm 0.1 ; P=0.07$ ) compared with intermediate count females $(3.3 \pm 0.1)$. The global average of AFC (all cows) changed during the early 
stages of pregnancy $(27.97 \pm 2.38 ; 30.80$ \pm 2.17 and $43.60 \pm 3.06$ at $\mathrm{Al}$ and 30 and 60 days of pregnancy, respectively; $P<0.001$ ).
A 1.5-fold increase in follicle count was observed between the day of $\mathrm{Al}$ and 60 days of pregnancy (Figure 2).

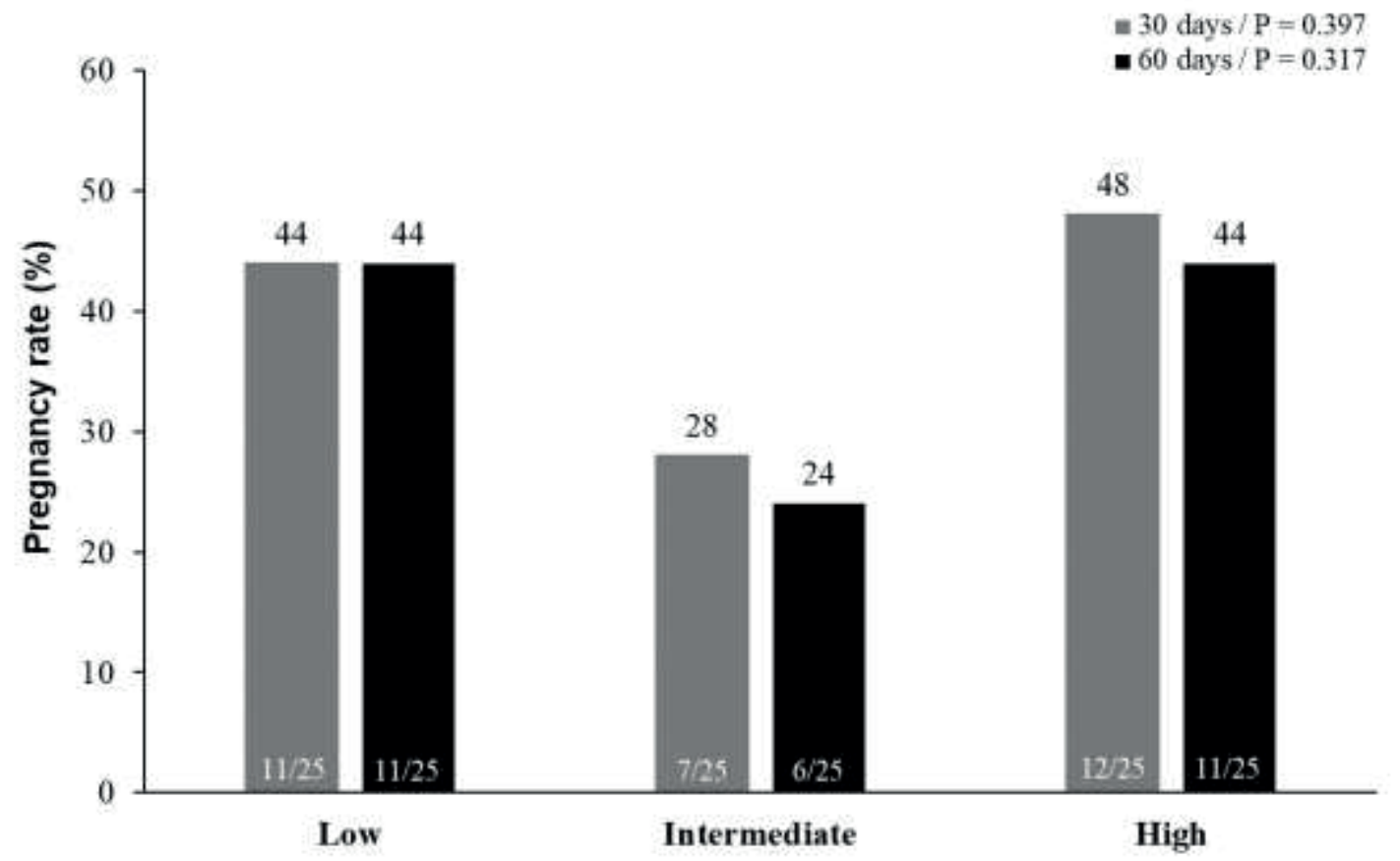

Figure 1. Conception rate of Holstein cows submitted to artificial insemination (AI) at 30 and 60 days of pregnancy based on low, intermediate, and high antral follicle count (AFC) groups.

The number of antral follicles in females with low AFCs increased as the pregnancy progressed $(P<0.001)$. At 60 days of pregnancy, AFC values were similar to that observed in the high-AFC group (Figure 3). A positive effect $(P=0.001)$ on follicle number from day 0 to 60 days of gestation was also observed in the intermediate AFC group. However, no difference in AFCs was noted in the high-AFC group at different time points $(P>0.1)$. Furthermore, at $\mathrm{Al}$ and 30 days of pregnancy, AFCs among the low-, intermediate-, and high-AFC groups differed (P<0.001; Figure 3). 
Table 1

Productive and reproductive parameters of Holstein cows with low ( $\leq 18$ follicles), intermediate ( $\geq 24$ and $\leq \mathbf{2 8}$ follicles), and high antral follicle count (AFC; $\geq 30$ follicles)

\begin{tabular}{|c|c|c|c|c|}
\hline Variables & $\begin{array}{l}\text { Low-AFC } \\
(\mathrm{M} \pm \mathrm{SE})\end{array}$ & $\begin{array}{l}\text { Intermediate- } \\
\text { AFC (M } \pm \text { SE) }\end{array}$ & $\begin{array}{l}\text { High-AFC } \\
(\mathrm{M} \pm \mathrm{SE})\end{array}$ & P-value \\
\hline Animals (n) & 25 & 25 & 25 & - \\
\hline $\operatorname{AFC}(n)$ & $15.0 \pm 0.6^{c}$ & $24.3 \pm 0.4^{b}$ & $42.8 \pm 1.8^{a}$ & $<0.0001$ \\
\hline Age (months) & $57.9 \pm 2.0$ & $56.1 \pm 2.0$ & $61.4 \pm 3.5$ & 0.34 \\
\hline BW (kg) & $583.5 \pm 17.7^{b}$ & $622.3 \pm 14.1 \mathrm{ab}$ & $642.4 \pm 12.6^{a}$ & 0.02 \\
\hline BCS (1 to 5$)$ & $3.5 \pm 0.1 \mathrm{ab}$ & $3.3 \pm 0.1^{b}$ & $3.6 \pm 0.1^{a}$ & 0.07 \\
\hline Calving order (n) & $1.8 \pm 0.1$ & $1.8 \pm 0.1$ & $2.0 \pm 0.2$ & 0.48 \\
\hline Days in milk (days) & $295.2 \pm 69.5$ & $229.0 \pm 58.3$ & $377.0 \pm 64.4$ & 0.26 \\
\hline CL diameter at PD 30 days (mm) & $23.7 \pm 0.7$ & $23.0 \pm 0.1$ & $21.7 \pm 0.1$ & 0.33 \\
\hline Dominant follicle diameter at $\mathrm{Al}(\mathrm{mm})$ & $17.2 \pm 0.7 \mathrm{ab}$ & $18.0 \pm 0.7^{a}$ & $15.8 \pm 0.5^{b}$ & 0.04 \\
\hline Ovary diameter (mm) & $28.3 \pm 0.9$ & $29.6 \pm 0.6$ & $30.8 \pm 0.7$ & 0.28 \\
\hline
\end{tabular}

Values followed by superscripted lowercase letters (a-c) within the same line indicate significant difference among groups (low, intermediate and high antral follicle count (AFC). BW - body weight, BCS - body condition score, CL - corpus luteum, PD - pregnancy diagnosis, Al - artificial insemination.

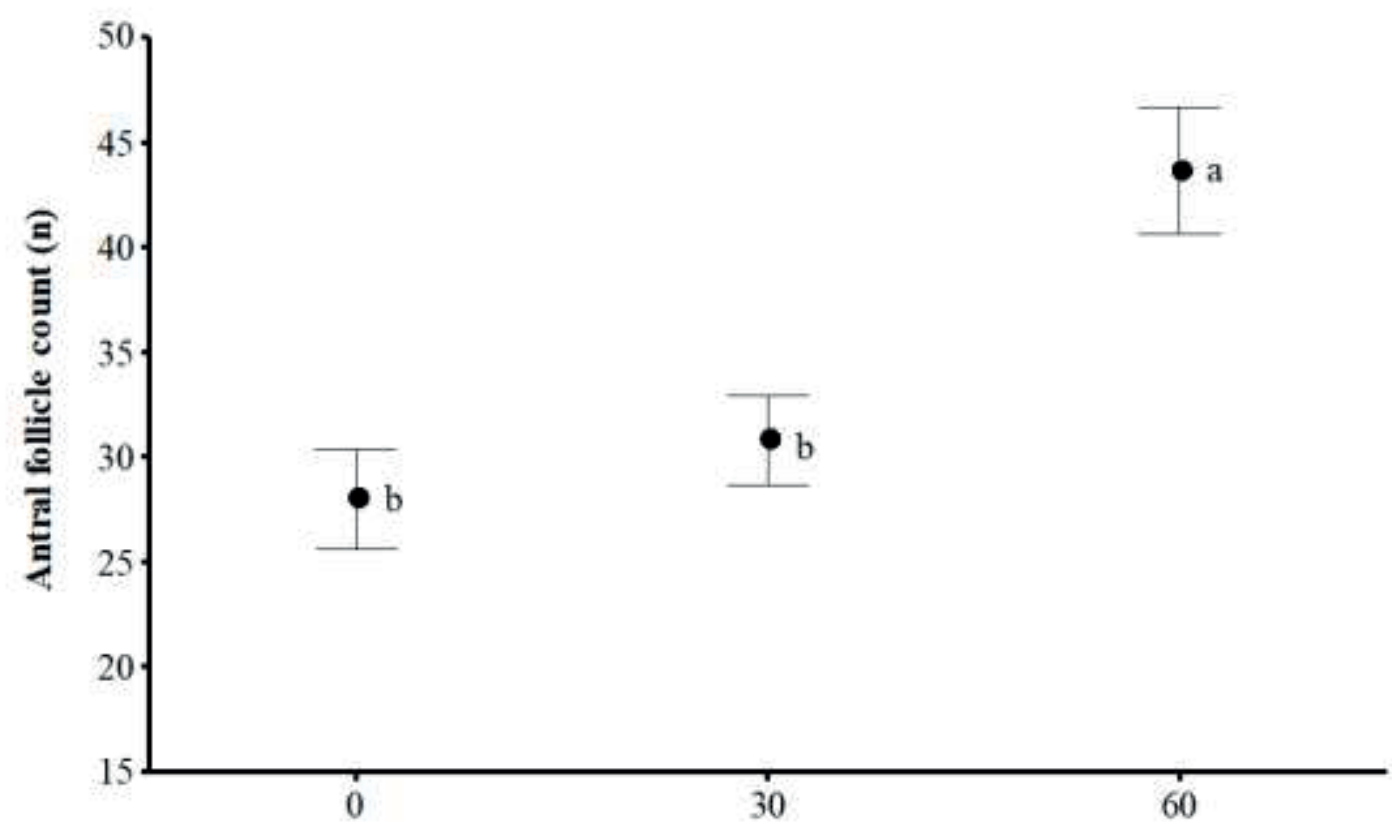

\section{Day of gestation}

Figure 2. Number of antral follicles in Holstein cows $(n=35)$ at the moment of artificial insemination (day 0; nonpregnant) and 30 and 60 days of pregnancy. Lowercase letters (a-b) indicate a difference $(P \leq 0.0001)$ of antral follicle count (AFC) among the moments of evaluation. 
Holstein heifers presented an increase of the mean number of viable oocytes (30.56 \pm 3.45 vs.13.77 \pm 3.63; $P=0.02)$ and total oocytes $(41.67 \pm 3.79$ vs. $17.43 \pm 4.52 ; \mathrm{P}=$ 0.001 ) when OPU was performed from 0 to 30 days of pregnancy compared to before $\mathrm{Al}$ (nonpregnant), respectively (Table 2). However, the rate of viable oocytes was similar $(P=$ 0.54) among times. Regarding in vitro embryo production data, pregnancy status was also positively affected. An increased total number of embryos was produced during the first 30 days of pregnancy $(4.55 \pm 0.75)$ than before Al (1.39 $\pm 0.85 ; P=0.07$, Table 2). In addition, blastocyst rates were increased in heifers when pregnant (31 to 60 days of pregnancy, $18.90 \pm 4.91)$ compared to nonpregnant heifers $(7.59 \pm 3.25 ; P=0.05)$. However, after the establishment of pregnancy, both the number of embryos and the blastocyst rate remained constant throughout the evaluated periods (Table 2).

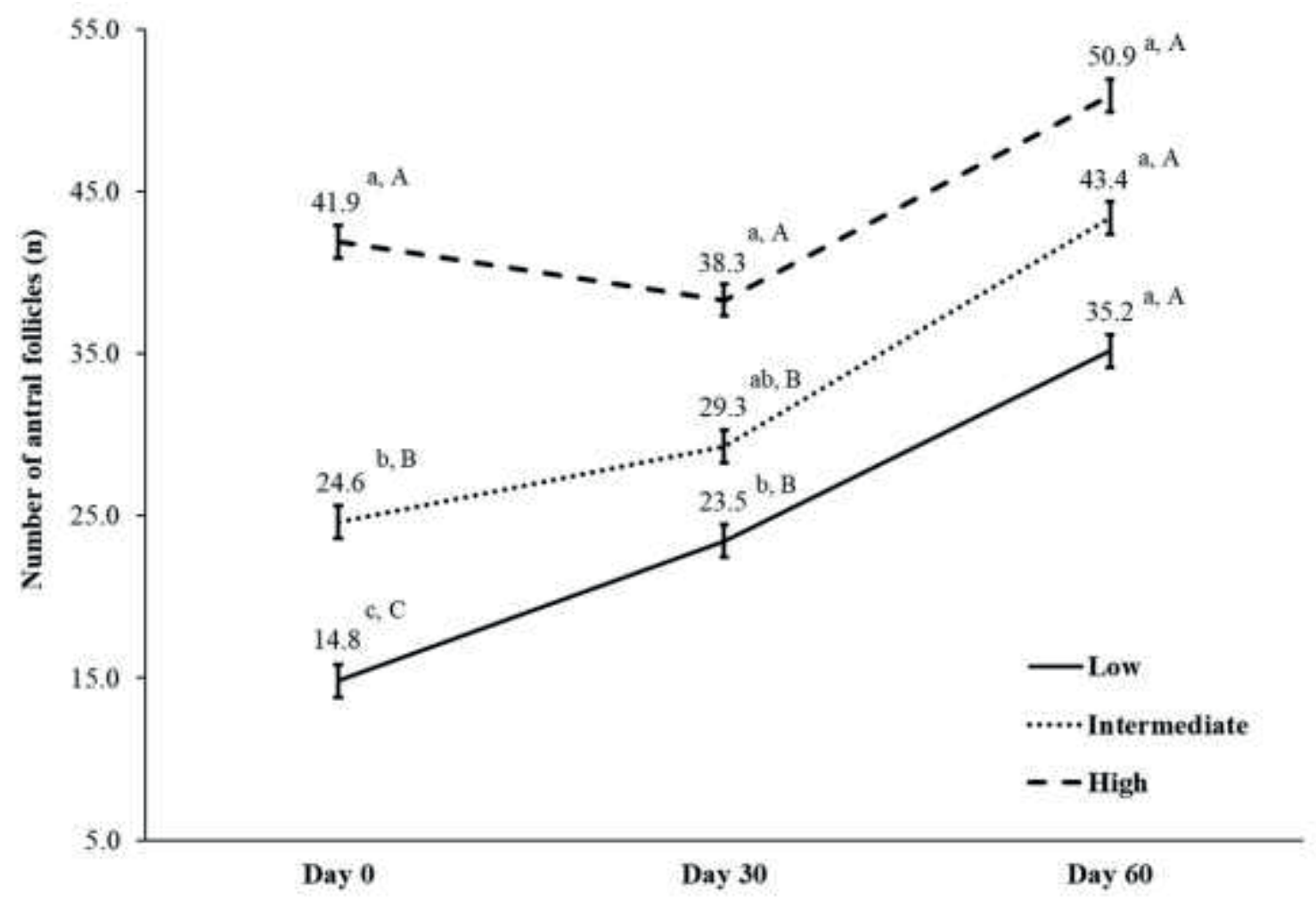

Figure 3. Number of antral follicles in Holstein cows with low ( $\leq 18$ follicles; $n=11)$, intermediate $(\geq$ 24 and $\leq 28$ follicles; $n=11$ ) and high antral follicle count ( $A F C ; \geq 30$ follicles; $n=13$ ) at the moment of artificial insemination (day 0; nonpregnant) and at 30 and 60 days of pregnancy. Different lowercase letters $(\mathrm{a}-\mathrm{c})$ on the same time (day 0,30 , or 60 ) indicate a significant difference $(P \leq 0.05)$ between the number of antral follicles of the AFC groups. Different capital letters $(A, B)$ for the same antral follicle count (AFC) group indicate a significant difference between the number of antral follicles at different times of evaluation. 


\section{Table 2}

\section{Performance of in vitro embryo production in Holstein heifers before pregnancy (nonpregnant) and at different times from first gestational third}

\begin{tabular}{|c|c|c|c|c|c|}
\hline \multirow[b]{2}{*}{ Variables } & \multicolumn{5}{|c|}{ Status/Time pregnancy } \\
\hline & $\begin{array}{l}\text { No pregnancy } \\
(\mathrm{m} \pm \mathrm{se})\end{array}$ & $\begin{array}{l}0 \text { to } 30 \text { days } \\
\text { ( } m \pm s e)\end{array}$ & $\begin{array}{l}31 \text { to } 60 \text { days } \\
\text { ( } m \pm s e)\end{array}$ & $\begin{array}{c}>60 \text { days } \\
(\mathrm{m} \pm \mathrm{se})\end{array}$ & P-value \\
\hline Pregnancy time (days) & - & $17.67 \pm 2.93 c$ & $51.80 \pm 3.27 b$ & $80.56 \pm 5.93 a$ & $<0.0001$ \\
\hline Viable oocytes (n) & $13.77 \pm 3.63 b$ & $30.56 \pm 3.45 a$ & $21.50 \pm 2.21 \mathrm{ab}$ & $25.22 \pm 3.63 b$ & 0.02 \\
\hline Total oocytes (n) & $17.43 \pm 4.52 \mathrm{c}$ & $41.67 \pm 3.79 a$ & $26.60 \pm 2.16 b c$ & $34.22 \pm 4.82 \mathrm{ab}$ & 0.001 \\
\hline Viable oocytes (\%) & $79.96 \pm 4.77$ & $72.24 \pm 4.62$ & $79.83 \pm 3.08$ & $75.14 \pm 4.21$ & 0.54 \\
\hline Total embryos (n) & $1.39 \pm 0.85 b$ & $4.55 \pm 0.75 a$ & $4.15 \pm 1.36 \mathrm{ab}$ & $3.87 \pm 0.93 a b$ & 0.07 \\
\hline Embryos rate (\%) & $7.59 \pm 3.25 b$ & $13.46 \pm 2.33 \mathrm{ab}$ & $18.90 \pm 4.91 \mathrm{a}$ & $18.67 \pm 4.17 \mathrm{ab}$ & 0.05 \\
\hline
\end{tabular}

Values followed by superscripted lowercase letters (a-c) within the same line indicate significant difference among the time points: no pregnancy, 0 to 30 days, 31 to 60 days, and $>60$ days of pregnancy.

This study confirmed our initial hypothesis in dairy cattle that AFC is subject to a variation from the moment before pregnancy until the establishment of pregnancy in its initial third. In addition, these same conditions (pregnancy status and periods) can determine the impacts on the efficiency of IVEP. In Study I, we demonstrate that the AFC increased in early gestation of Holstein cows with a 1.5-fold increase between the day of $\mathrm{Al}$ and day 60 of pregnancy. Interestingly, animals categorized with low AFCs exhibited the greatest increase in the number of antral follicles as pregnancy progressed. Moreover, at 60 days of pregnancy, the number of antral follicles was similar between females with low and high AFCs. Thus, our results suggest that the initial period of pregnancy is possibly the best time to optimize and perform follicular aspiration in Holstein cows, and improvements in this process are more evident in low- to intermediate-AFC donors due to the increase in the number of antral follicles with the establishment of pregnancy. In this context, the results obtained in Study II with Holstein heifers support study I by demonstrating that OPU performed after the establishment of pregnancy (regardless of the period of pregnancy) resulted in improvements in oocyte and embryonic quantity and quality, increasing the efficiency of the IVEP program compared to the nonpregnant moment in these same females.

Comparing different categories of Holstein females (prepubertal, pubertal and pregnant heifers), Takuma et al. (2010) observed that pregnant heifers (at 30 to 90 days of pregnancy) exhibited an increased proportion of medium $(6-10 \mathrm{~mm})$ and large (>10 $\mathrm{mm}$ ) follicles. In the present study, AFC was not quantified by the size of the follicles; however, our findings are consistent. In addition, it should be noted that since the 1990s, performing OPU in females in the first trimester of pregnancy has been described as a safe method for oocyte recovery (Meintjes, Bellow, Broussard, Paul, \& Godke, 1995).

The reasons for the increase in the number of antral follicles during pregnancy 
is still not understood but may be related to endocrine and metabolism changes involved with pregnancy. Early pregnancy is considered an anabolic state in the mother's body with increasing rates of fat deposition and increases in insulin sensitivity (Zeng, Liu, \& Li, 2017). Changes to an anabolic state may promote changes in liver blood flow, local and circulating metabolic factors (glucose and insulin-like growth factor type 1, IGF1), and hormone concentrations (insulin and steroids; Sartori et al., 2013). In addition, high P4 levels promote reduced smooth muscle tone and decreased gastrointestinal transit rate, which may result in advantages for nutrient absorption due to long contact with absorption sites and consequently may result in an increase in the plasma glucose concentration (Coad \& Dunstall, 2011).

Although we have not tested this hypothesis, it may be suggested that the increase in AFC in relation to pregnancy may be related to changes in endocrine and metabolic rates. Changes in ovarian follicular growth pattern and luteal function may be related to variations in lipoprotein and cholesterol synthesis; increased circulating concentrations of ovarian steroids; differences in growth hormone secretion, insulin, and synthesis; and accumulation of IGF-1 in ovarian cells (Spicer, Alpizar, \& Echternkamp, 1993; Williams \& Stanko, 2000; Webb, Garnsworthy, Gong, \& Armstrong, 2004).

Moreover, considering the lack of studies on the influence of the AFC on Bos $t$ t taurus subjected to $\mathrm{Al}$ under management conditions in Brazil, the present study revealed no difference in conception rate at 30 and 60 days of pregnancy between females with high and low AFCs. This finding corroborates data from studies with Bos $t$. indicus (Nelore) that were performed in Brazil (Morotti et al., 2018) and Bos t. taurus (Holstein) that were performed in USA (Jimenez-Krassel et al., 2017), which did not confirm increased conception rate performance for animals with a high AFC.

Regarding reproductive characteristics, no differences in the diameter of $C L$ and ovaries (at the time of estrus) were noted among the AFC groups. Data were contrary to those found by other authors who observed differences among the AFC groups when performing ovariectomy and ultrasound evaluations at various times in the estrous cycle (J. L. H. Ireland et al., 2008) or when using a computerized system (Martinez et al., 2016). Thus, the discrepancy between the results is potentially related to the differences in the method used to evaluate such parameters.

Our results show that the diameter of the dominant follicle was reduced in animals with high vs. intermediate AFCs. Other researchers found a similar result in Bos $t$. indicus and beef taurines (Morotti et al., 2018; Pfeifer, Souza Leal, Schneider, Schmitt, \& Corrêa, 2012). We also saw that the weight of the high AFC animals was increased compared with that observed in the low AFC group, and this same observation occurred for BCS in cows with high vs. intermediate AFCs.

The number of antral follicles is associated with higher levels of embryo production in vitro (J. Ireland et al., 2007; Santos et al., 2016) and in vivo (Center, Dixon, Looney, \& Rorie, 2018; Silva-Santos et al., 2014). Since an increase in the number of antral follicles is associated with the early stage of pregnancy, it would be quantitatively advantageous to aspirate pregnant cows than nonpregnant cows. The mean number of viable and total oocytes increased at 0 - 
30 days of pregnancy compared to before Al (nonpregnant). Similar data were obtained by a study with mares, in which more oocytes were recovered at a greater percent recovery per follicle in pregnant mares compared with cycling or transitional mares, mainly at day 25 of pregnancy (Purcell et al., 2007).

Furthermore, the mean total embryos number and rates were increased after pregnancy (during the first 30 days and 31 - 60 days, respectively) compared to the nonpregnant phase. These data corroborate a study that compared Japanese black cows pregnant (60 - 90 days of pregnancy) and nonpregnant submitted to OPU/IVEP, which reported increased embryonic production and better quality of embryos obtained from pregnant females (Takuma et al., 2010). Additionally, the developmental competence of oocytes obtained from pregnant cows was increased compared with that obtained from nonpregnant cows.

Finally, we highlight the potential of the findings of this study that reinforce the use of AFC as a tool for female classification and the use of OPU in strategic moments of the donor's pregnancy status. The results reported here demonstrate that the pregnancy status positively influences both the number of antral follicles as well as the quality and quantity of oocytes and embryos, improving the efficiency of IVEP programs in dairy cattle.

\section{Conclusions}

In conclusion, AFC in Holstein cows is positively influenced by pregnancy, and this effect mainly occurs in females with low AFCs. Our results suggest that the strategy of using cows in this category as oocyte donors when early in pregnancy is the most efficient. The present study also showed that for Bost. taurus females subjected to Al under management conditions in Brazil, the conception rate at $\mathbf{3 0}$ and 60 days of pregnancy was similar between the high and low AFC groups. Furthermore, the pregnancy status improved oocyte recovery and embryonic production in Holstein heifers, indicating that the initial phase of pregnancy is the best period to perform the OPU and improve the performance of IVEP programs in dairy cattle.

\section{Conflict of interest}

None of the authors have any conflicts of interest to declare.

\section{Acknowledgments}

The authors acknowledge the Coordination for the Improvement of Higher Education Personnel (CAPES), the Postgraduate Program in Animal Science at the State University of Londrina, the Postgraduate Program in Clean Technologies (PPGTL), University Center Cesumar/UNICESUMAR, and the National Council for Scientific and Technological Development (CNPq) for providing financial support.

\section{References}

Burns, D. S., Jimenez-Krassel, F., Ireland, J. L. H., Knight, P. G., \& Ireland, J. J. (2005). Numbers of antral follicles during follicular waves in cattle: evidence for high variation among animals, very high repeatability in individuals, and an inverse association with serum follicle stimulating 
hormone concentrations. Biology of Reproduction, 73(1), 54-62. doi: 10.1095/ biolreprod.104.036277

Center, K., Dixon, D., Looney, C., \& Rorie, R. (2018). Anti-mullerian hormone and follicle counts as predictors of superovulatory response and embryo production in beef cattle. Advances in Reproductive Sciences, 6(1), 22-33. doi: 10.4236/ars ci.2018.61003

Claes, A., Ball, B. A., Scoggin, K. E., Roser, J. F., Woodward, E. M., Davolli, G. M., Squires, E. L., Troedsson, M. H. T. (2017). The influence of age, antral follicle count and diestrous ovulations on estrous cycle characteristics of mares. Theriogenology, 97(15), 34-40. doi: 10.1016/j.theriogeno logy. 2017.04.019

Coad, J., \& Dunstall, M. (2011). Anatomy and physiology for midwives (3nd ed.). London: Churchill Livingstone.

Cushman, R. A., Allan, M. F., Kuehn, L. A., Snelling, W. M., Cupp, A. S., \& Freetly, H. C. (2009). Evaluation of antral follicle count and ovarian morphology in crossbred beef cows: Investigation of influence of stage of the estrous cycle, age, and birth weight1, 2. Journal of Animal Science, 87(6), 1971-1980. doi: 10.2527/jas.20081728

Evans, A., Mossa, F., Walsh, S., Scheetz, D., Jimenez-Krassel, F., Ireland, J. L. H.,... Ireland, J. J. (2012). Effects of maternal environment during gestation on ovarian folliculogenesis and consequences for fertility in bovine offspring. Reproduction in Domestic Animals, 47(4), 31-37. doi: 10.1111/j.1439-05 31.2012.02052.x

Ferguson, J. D., Galligan, D. T., \& Thomsen, N. (1994). Principal descriptors of body condition score in holstein cows. Journal of Dairy Science, 77(9), 2695-2703. doi: 10.3168/jds.S0022-0302(94)77212-X

Gonçalves, G. R., Morotti, F., Colombo, A. H. B., Bonato, D. V., Bizarro-Silva, C., Rosa, C. O.,... Seneda, M. M. (2020). Influence of age and ovarian antral follicle count on the reproductive characteristics of embryo donor mares. Veterinary Record, 186(17), 564-564. doi: 10.1136/vr.105526

Ireland, J., Ward, F., Jimenez-Krassel, F., Ireland, J. L. H., Smith, G. W., Lonergan, P., \& Evans, A. C. O. (2007). Follicle numbers are highly repeatable within individual animals but are inversely correlated with FSH concentrations and the proportion of good-quality embryos after ovarian stimulation in cattle. Human Reproduction, 22(6), 1687-1695. doi: 10.1093/humrep/ dem071

Ireland, J. J., Smith, G. W., Scheetz, D., JimenezKrassel, F., Folger, J. K., Ireland, J. L. H.,... Evans, A. C. O. (2011). Does size matter in females? An overview of the impact of the high variation in the ovarian reserve on ovarian function and fertility, utility of antiMüllerian hormone as a diagnostic marker for fertility and causes of variation in the ovarian reserve in cattle. Reproduction, Fertility and Development, 23(1), 1-14. doi: $10.1071 / R D 10226$

Ireland, J. L. H., Scheetz, D., Jimenez-Krassel, F., Themmen, A. P. N., Ward, F., Lonergan, P.,... Ireland, J. J. (2008). Antral follicle count reliably predicts number of morphologically healthy oocytes and follicles in ovaries of young adult cattle. Biology of Reproduction, 79(6), 12191225. doi: 10.1095/biolreprod.108.071 670 
Jimenez-Krassel, F., Folger, J. K., Ireland, J. L. H., Smith, G. W., Hou, X., Davis, J. S.,... Ireland, J. J. (2009). Evidence that high variation in ovarian reserves of healthy young adults has a negative impact on the corpus luteum and endometrium during estrous cycles in cattle. Biology of Reproduction, 80(6), 1272-1281. doi: 10.1095/biolreprod.108.075093

Jimenez-Krassel, F., Scheetz, D. M., Neuder, L. M., Ireland, J. L. H., Pursley, J. R., Smith, G. W.,... Ireland, J. J. (2015). Concentration of anti-Müllerian hormone in dairy heifers is positively associated with productive herd life. Journal of Dairy Science, 98(5), 3036-3045. doi: 10.3168/jds.2014-8130

Jimenez-Krassel, F., Scheetz, D. M., Neuder, L. M., Pursley, J. R., \& Ireland, J. J. (2017). A single ultrasound determination of $\geq 25$ follicles $\geq 3 \mathrm{~mm}$ in diameter in dairy heifers is predictive of a reduced productive herd life. Journal of Dairy Science, 100(6), 5019-5027. doi: 10.3168/jds.2016-12277

Lonergan, P., Rizos, D., Ward, F., \& Boland, M. P. (2001). Factors influencing oocyte and embryo quality in cattle. Reproduction Nutrition Development, 41(5), 427-437. doi: 10.1051/rnd:2001142

Martinez, M. F., Sanderson, N., Quirke, L. D., Lawrence, S. B., \& Juengel, J. L. (2016). Association between antral follicle count and reproductive measures in New Zealand lactating dairy cows maintained in a pasture-based production system. Theriogenology, 85(3), 466-475. doi: 10. 1016/j.theriogenology.2015.09.026

Meintjes, M., Bellow, M. S., Broussard, J. R., Paul, J. B., \& Godke, R. A. (1995). Transvaginal aspiration of oocytes from hormone-treated pregnant beef cattle for in vitro fertilization. Journal of Animal Science, 73(4), 967-974. doi: 10. 2527/1995.734967x

Monteiro, F. M., Batista, E. O. S., Vieira, L. M., Bayeux, B. M., Accorsi, M., Campanholi, S. P.,... Baruselli, P. S. (2017). Beef donor cows with high number of retrieved COC produce more in vitro embryos compared with cows with low number of COC after repeated ovum pick-up sessions. Theriogenology, 90(1), 54-58. doi: 10.10 16/j.theriogenology.2016.11.002

Moraes, F. L. Z. de, Morotti, F., Costa, C. B., Lunardelli, P. A., \& Seneda, M. M. (2019). Relationships between antral follicle count, body condition, and pregnancy rates after timed-Al in Bos indicus cattle. Theriogenology, 136(15), 10-14. doi: 10. 1016/j.theriogenology.2019.06.024

Morotti, F., Moretti, R., Santos, G. M. G. dos, Silva-Santos, K. C., Ramos Cerqueira, P. H., \& Seneda, M. M. (2018). Ovarian follicular dynamics and conception rate in Bos indicus cows with different antral follicle counts subjected to timed artificial insemination. Animal Reproduction Science, 188(1), 170-177. doi: 10.1016/j. anireprosci.2017.12.001

Mossa, F., Walsh, S. W., Butler, S. T., Berry, D. P., Carter, F., Lonergan, P.,... Evans, A. C. O. (2012). Low numbers of ovarian follicles $\geq 3 \mathrm{~mm}$ in diameter are associated with low fertility in dairy cows. Journal of Dairy Science, 95(5), 2355-2361. doi: 10.3168/ jds.2011-4325

Nagai, K., Yanagawa, Y., Katagiri, S., \& Nagano, M. (2016). The relationship between antral follicle count in a bovine ovary and developmental competence of in vitrogrown oocytes derived from early antral 
follicles. Biomedical Research, 37(1), 6371. doi: 10.2220/biomedres.37.63

National Research Council (2001). Nutrient requirements of dairy cattle (7nd rev.). Washington, DC: National Academy Press.

Parrish, J. J., Krogenaes, A., \& Susko-Parrish, J. (1995). Effect of bovine sperm separation by either swim-up or Percoll method on success of in vitro fertilization and early embryonic development. Theriogenology, 44(6), 859-869. doi: 10.1016/0093-691X (95)00271-9

Pfeifer, L. F. M., Souza Leal, S. del C. B. de, Schneider, A., Schmitt, E., \& Corrêa, M. N. (2012). Effect of the ovulatory follicle diameter and progesterone concentration on the pregnancy rate of fixed-time inseminated lactating beef cows. Revista Brasileira de Zootecnia, 41(4), 1004-1008. doi: 10.1590/S151635982012000400024

Purcell, S. H., Seidel, G. E., McCue, P. M., \& Squires, E. L. (2007). Aspiration of oocytes from transitional, cycling, and pregnant mares. Animal Reproduction Science, 100(3-4), 291-300. doi: 10.1016/j.anire prosci.2006.07.009

Rosa, C., Marinho, L., Rosa, P. da, Cesaro, M. de, Lunardelli, P., Silva-Santos, K.,... Seneda, M. (2018). Molecular characteristics of granulosa and cumulus cells and oocyte competence in Nelore cows with low and high numbers of antral follicles. Reproduction in Domestic Animals, 53(4), 921-929. doi: 10.1111/rda.13189

Santos, G. M. G. dos, Silva-Santos, K. C., Barreiros, T. R. R., Morotti, F., Sanches, B. V., Moraes, F. L. Z. de.,... Seneda, M. M. (2016). High numbers of antral follicles are positively associated with in vitro embryo production but not the conception rate for FTAl in Nelore cattle. Animal Reproduction Science, 165(2), 17-21. doi: 10.1016/j.ani reprosci.2015.11.024

Sartori, R., Guardieiro, M., Surjus, R., Melo, L., Prata, A., Ishiguro, M.,... Nascimento, A. (2013). Metabolic hormones and reproductive function in cattle. Animal Reproduction, 10(3), 199-205.

Silva-Santos, K., Santos, G., Koetz, C., Jr., Morotti, F., Siloto, L., Marcantonio, T.,... Seneda, M. (2014). Antral follicle populations and embryo production - in vitro and in vivo - of bos indicus-taurus donors from weaning to yearling ages. Reproduction in Domestic Animals, 49(2), 228-232. doi: 10.1111/rda.12255

Spicer, L. J., Alpizar, E., \& Echternkamp, S. E. (1993). Effects of insulin, insulin-like growth factor I, and gonadotropins on bovine granulosa cell proliferation, progesterone production, estradiol production, and(or) insulin-like growth factor I production in vitro1. Journal of Animal Science, 71(5), 1232-1241. doi: $10.2527 / 1993.7151232 x$

Takuma, T., Sakai, S., Ichimaru, H., Jinnouchi, T., Kaedei, Y., Nagai, T., \& Otoi, T. (2010). Effects of season and reproductive phase on the quality, quantity and developmental competence of oocytes aspirated from japanese black cows. Journal of Reproduction and Development, 56(1), 55-59. doi: 10.1262/jrd.09-071h

Webb, R., Garnsworthy, P. C., Gong, J.-G., \& Armstrong, D. G. (2004). Control of follicular growth: local interactions and nutritional influences. Journal of Animal Science, 82(E-Suppl.), E63-74. doi: 10. 2527/2004.8213_supplE63x 
Williams, G. L., \& Stanko, R. L. (2000). Dietary fats as reproductive nutraceuticals in beef cattle. Journal of Animal Science, 77(E-Suppl.), 1. doi: 10.2527/jas2000.77ESuppl1n

Wright, J. (1998). Photomicrographic illustration of embryo codes. In S. M. Stringfellow, \& D. A. Seidel (Eds.), Manual of the international embryo transfer society (3nd ed., pp. 167-170). Savory, IL, USA, International Embryo Transfer Society.
Zeng, Z., Liu, F., \& Li, S. (2017). Metabolic adaptations in pregnancy: a review. Annals of Nutrition and Metabolism, 70(1), 59-65. doi: 10.1159/000459633

Zhang, Y., Xu, Y., Xue, Q., Shang, J., Yang, X., Shan, X.,... Zeng, C. (2019). Discordance between antral follicle counts and anti-Müllerian hormone levels in women undergoing in vitro fertilization. Reproductive Biology and Endocrinology, 17(1), 51-51. doi: 10.1186/s12958-0190497-4 